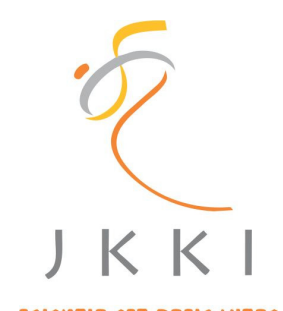

SCIENTIR EST BASIC VITAE

\section{Jurnal Kedokteran dan Kesehatan Indonesia}

\author{
Indonesian Journal of Medicine and Health
}

Journal homepage: https://journal.uii.ac.id/JKKI

\title{
The correlation between skin type and acne scar severity in young adults
}

Yessica Mishellin Awaloei ${ }^{1}$, Nawanto Agung Prastowo ${ }^{2}$, Regina Regina*3

${ }^{1}$ Bachelor of Medicine Study Programme, School of Medicine and Health Sciences, Atma Jaya Catholic University of Indonesia, Jakarta, Indonesia

${ }^{2}$ Department of Physiology, School of Medicine and Health Sciences, Atma Jaya Catholic University of Indonesia, Jakarta, Indonesia

${ }^{3}$ Department of Dermatology and Venereology, School of Medicine and Health Sciences, Atma Jaya Catholic University of Indonesia, Jakarta, Indonesia

Original Article

\begin{tabular}{l}
\hline \\
\hline ARTICLE INF O \\
\hline Keywords: \\
acne vulgaris, \\
acne scar, \\
skin types \\
*Corresponding author: \\
regina@atmajaya.ac.id \\
\hline DOI:10.20885/JKKI.Vol12.Iss1.art9 \\
\hline History: \\
Received: November 28, 2020 \\
Accepted: April 22, 2021 \\
Online: April 30, 2021 \\
\hline Copyright @2021 Authors. \\
This is an open access article \\
distributed under the terms \\
of the Creative Commons At- \\
tribution-NonCommercial 4.0 \\
International Licence (http:// \\
creativecommons.org/licences/ \\
by-nc/4.0/).
\end{tabular}

\section{ABSTRACT}

Background: Acne is the most common skin disorder, especially in adolescents and youths. Inflammation due to acne may leave scar tissue. The scar severity may correlate with gender and skin type.

Objective: This study aims to investigate the correlation between gender, skin type, and acne scar severity in youth.

Methods: This is a cross-sectional study with 132 (81 female) medical college students aged from 18 to 23 participated in the study. Skin type was assessed using a Baumann Skin Type questionnaire. Acne scar severity was evaluated using the Qualitative Global Scarring Grading. Skin examination was conducted through the image from the face photograph. Lambda test was used to confirm the correlation between gender, skin type, and acne scar severity. Multiple logistic regression was applied to determine the odd risk of gender and skin type to moderate-severe acne scar. Significance was set at $\mathrm{p}<0.05$.

Results: Most of the participants $(80.3 \%)$ had oily skin, and 22 participants $(16.7 \%)$ had moderate-severe acne scar. A weak positive correlation was confirmed between skin type and acne scar severity $(\mathrm{p}<0.01, \mathrm{r}=0.3)$. Oily skin type has 4.3 times greater risk of developing more severe acne scar $(\mathrm{p}<0.01,95 \% \mathrm{CI}=1.90-9.90)$.

Conclusion: Skin type is correlated with acne scar severity. Oily skin type is at greater risk of developing severe acne scar.

Latar Belakang: Jerawat adalah kelainan pada kulit yang paling umum dijumpai, terutama pada remaja dan usia muda. Peradangan akibat jerawat dapat menyisakan jaringan skar. Derajat keparahan jaringan skar mungkin berkorelasi dengan jenis kelamin dan jenis kulit.

Tujuan: Penelitian ini bertujuan untuk mengetahui korelasi antara jenis kelamin, jenis kulit dan derajat keparahan jaringan skar.

Metode: Desain Penelitian ini adalah potong lintang. Sebanyak 132 orang (81 perempuan) mahasiswa kedokteran dalam rentang usia 18-23 tahun ikut berpartisipasi pada penelitian ini. Jenis kulit ditentukan dengan menggunakan kuesioner jenis kulit dari Baumann. Derajat keparahan skar akne dinilai dengan Qualitative Global Scarring Grading. Pemeriksaan kulit dilakukan secara tidak langsung melalui foto wajah. Uji Lambda digunakan untuk mengetahui korelasi antara jenis kelamin, jenis kulit, dan derajat keparahan skar akne. Regresi logistik multipel dipergunakan untuk mengetahui OR jenis kelamin dan jenis kulit terhadap derajat skar akne sedang berat. 
Hasil: Sebanyak 106 partisipan memiliki jenis kulit berminyak (80.3\%) dan 22 orang lainnya memiliki derajat sedang berat (16.7\%). Terdapat korelasi positif yang lemah antara tipe kulit dengan derajat keparahan skar akne $(p<0.01, r=0.3)$. Jenis kulit berminyak memiliki risiko 4.3 kali lebih besar mengalami derajat skar akne sedang-berat $(p<0.01$, 95\% CI = 1.90-9.90).

Kesimpulan: Jenis kulit berkorelasi dengan derajat keparahan skar akne. Jenis kulit berminyak memiliki risiko lebih besar mengalami derajat keparahan skar akne lebih berat.

\section{INTRODUCTION}

Acne is the most common skin disorder and often occurs in adolescents. Acne vulgaris (AV) is a chronic inflammation of the pilosebaceous follicular. ${ }^{1}$ The pathogenesis of $\mathrm{AV}$ includes several factors, such as increased sebum production, hyperproliferation of pilosebaceous follicles, Propionibacterium acnes colonization, and inflammatory processes. ${ }^{2}$ Inflammatory process due to $\mathrm{AV}$ can cause a post-inflammation scar. It is predicted that around $95 \%$ of people with AV will have acne scars with different morphologies. ${ }^{3}$

There are two skin types based on sebum production produced by sebaceous glands, oily skin and dry skin. Oily skin is marked with high sebum levels, whereas dry skin is indicated with low sebum production. ${ }^{4}$ Sebum contains pro-inflammatory chemical mediators that trigger innate immune defense response. This can aggravate the inflammatory process in the pilosebaceous unit. ${ }^{5}$ The chronic inflammation in the pilosebaceous will lead to damage of skin's microscopic structure, which results in the formation of acne scars. Acne scars impact changes in color, texture, or both, which contrast with normal skin around it. ${ }^{3,6}$

The AV scars are the most common cause of facial disfiguration, especially among adolescents, considering the hormonal changes caused by puberty in their age. The thoughts of the youths are more dominated by certain issues; especially bodily changes they experience during their puberty. Youths tend to become excessively obsessed by their appearance. The AV scars tend to stay for a long time, and the location on the face, which is the center of attention when interacting with other people, harms the psychosocial aspect and ultimately disrupts the patient's quality of life. Moreover, in this $21^{\text {st }}$ century, as technologies develop, youths tend to spend more time in social media, causing further harm to their psychological conditions as they have been preoccupied with new beauty standards set by the society, which one of them is having clear and flawless skin..$^{7-9}$

Based on the results of some previous studies, this study aimed to examine the correlation between skin types and acne scar severity. This study might be one of the few studies investigating the correlation between skin types and acne scar severity in young adults. This study's results could be useful in the prevention and treatment of scar acne or to reduce the severity.

\section{METHODS \\ Study Design}

This was a cross-sectional study involving total of 132 participants, consisted of 51 males and 81 females. They were college students of the Faculty of Medicine and Health Sciences, Atma Jaya Catholic University of Indonesia who have provided written informed consent after explanation. This study has been approved by the Ethical Review Board of Atma Jaya Catholic University of Indonesia (Number: 23/06/KEPFKUAJ/2020). This study was conducted from March to August 2020.

Inclusion criteria were set as follows: students who experienced acne and within the age range of 18-23. Exclusion criteria included: under treatment of acne, using topical or oral drug to control sebum production, and other skin disorders.

\section{Study Setting}

The skin type was determined through the Baumann Skin Type questionnaire. The Baumann Skin Type questionnaire consists of 11 questions. Each question had 4-5 optional answers (A to D 
or A to E). Each item option had a specific score; $A=1, B=2, C=3, D=4$, and $E=2.5$. The score of each item option was then sum up. The total score of the 11 questions was then classified. The total score of 11-16 is classified as 'dry' skin, 17-26 as 'slightly dry,' 27-33 as 'slightly oily,' and 3444 as 'very oily' group. ${ }^{4}$ For statistical purposes, 'slightly dry' was combined into the 'dry' group whereas 'slightly oily' into the 'oily' group.

The severity of acne scars was determined through the Qualitative Global Scarring Grading (QGSC) System. The results of the QGSC system were categorized into four groups, macular scars (score 1), mild scar (score 2), moderate scar (score 3), and severe scar (score 4 ).$^{10}$ For the statistical purpose, macular and mild scar were combined into the 'light' group, whereas moderate and severe into 'moderate-severe' group. To avoid physical contact during the physical distancing policy during the Covid-19 pandemic, the participants were asked to take a photograph of their face and sent it to the researcher. The images were analyzed and assessed by a dermatologist.

\section{Data Analysis}

The numerical data was present as mean \pm standard deviation, while the categorical data as frequency and percentage (\%). The correlation between gender, skin type, and acne scar severity was tested using Lambda for ordinal data. Multiple logistic regression was applied to determine the Odds Ratio of gender and skin types to acne scar severity. Significance was set at $\mathrm{p}<0.05$.

\section{RESULTS}

The characteristic of the participants was described in Table 1. Most of the participants were female (61.4\%). Most participants had oily skin type $(80.3 \%)$ and light acne scar grade $(83.3 \%)$. The correlation between gender, skin type, and acne scar severity was presented in Table 2. Lambda was applied for the correlation between those variables. There was no correlation between gender and skin types as well as gender and acne scar severity (all $\mathrm{p}>0.05$ ). The correlation between skin types and acne scar severity was significant with a weak correlation $(p=0.000, r=0.3$ )

Table 1. The characteristic of the participants

\begin{tabular}{lc}
\hline \multicolumn{1}{c}{ Variables } & mean \pm SD $(\%)$ \\
\hline Age & $19.7 \pm 1.03$ \\
Gender & \\
Female & $81(61.4 \%)$ \\
Male & $51(38.6 \%)$ \\
Skin type & \\
Dry & $26(19.7 \%)$ \\
Oily & $106(80.3 \%)$ \\
Acne scar grade & \\
Light & $110(83.3 \%)$ \\
Moderate-severe & $22(16.7 \%)$ \\
\hline
\end{tabular}

Table 2. The correlation between variables.

\begin{tabular}{lcc}
\hline & $\begin{array}{c}\text { Skin type } \mathbf{r} \\
\text { (p-value) }\end{array}$ & $\begin{array}{c}\text { Acne scar grade } \mathbf{r} \\
\text { (p-value) }\end{array}$ \\
\hline Gender & $0.06(\mathrm{p}=0.68)$ & $0.02(\mathrm{p}=0.25)$ \\
Skin type & & $0.36(\mathrm{p}=0.000)$ \\
\hline
\end{tabular}


Table 3. described the Odd risk (OR) of gender and skin type to acne scar severity. Female and dry skin type was set as references. There is no different risk of gender ( $\mathrm{p}=0.66)$. Oily skin had OR 4.31 to experience moderate-severe acne scar severity $(\mathrm{p}=0.000)$.

Table 3. Logistic regression of gender and skin types to acne scar severity

\begin{tabular}{llccc}
\hline & & OR & $\mathbf{9 5 \%}$ CI & p \\
\hline Gender & Female & 0.80 & $0.30-2.17$ & 0.66 \\
& Male & & & \\
Skin Type & $\begin{array}{l}\text { Dry skin } \\
\text { Oily skin }\end{array}$ & 4.31 & $1.90-9.90$ & 0.000 \\
\hline
\end{tabular}

\section{DISCUSSION}

There are many studies in acne and skin type, and acne scar might have been conducted. Our study is also one of the studies investigating the correlation between skin types and acne scar severity in youth. Our study's critical finding is that skin types had a significant weak positive correlation with acne scar severity. Besides, oily skin had a risk of 4.31 times than dry skin to have more severe acne scar. We found no correlation between gender and skin types, as well as acne scar severity.

Some previous studies demonstrated similar findings with our study. Kartinayanti investigated the sebum level, and acne scar severity found that the sebum level had a significant weak positive correlation with acne scar severity. ${ }^{11}$ The weak positive correlation might be due to the amount of relatively smaller sample size taken compared to the number of samples of this recent study. Moreover, most of the respondents had normal skin and light acne scar severity, only very few had moderate to severe acne scar severity, causing the data result to be limited. A study conducted by Yosipovitch et al., involving a large sample of 94 high school students in Singapore, showed result of a weak positive correlation between the sebum level and the severity of acne inflammation..$^{12}$ Choi et al., in their study, also found a significant correlation between sebum and inflammation. This finding indicated that sebum production played an essential role in the development of inflammatory lesions. ${ }^{13}$ Excessive sebum production can lead to obstruction of the pilosebaceous follicles. This obstruction causes the lesion's environment to become anaerobic that supports $P$. acnes to develop and colonize. This condition can lead to worsening the inflammation lesion.

This recent study found that oily skin had a 4.3 times greater risk of experiencing moderatesevere scar acne vulgaris than dry skin type. The almost similar results were reported by Istiningdyah that found the participants with more severe inflammatory reactions had 11.2 times greater risk of developing a more severe acne scar. ${ }^{14}$ The relatively higher risk found in study conducted by Istiningdyah might be due to several other factors which cause inflammation where one of them is skin type, meanwhile this recent study solely focus on the skin type effect toward acne scar severity. The correlation between the severity of inflammation and the severity of acne scarring was also reported by Layton et al. ${ }^{15}$ The correlation was also confirmed by Holland et al. that found a strong correlation between the severity of inflammation and the severity of acne scarring. ${ }^{16}$ However, Layton et al. and Holland et al. did not report how much risk developing a more severe acne scar. ${ }^{15,16}$

Sex differences in skin anatomy, physiology, and disorders exist. Li et al. reported that the skin of females was more hydrated than that of males. ${ }^{17}$ Conversely, a study by Luebberding and Krueger found that stratum corneum in males showed a higher level of hydration than that of females. ${ }^{18}$ Concerning skin disorders, infectious diseases were more frequent in males, whereas 
psychosomatic-related disorders were more present in females. ${ }^{19}$

While concerning sebum production, males produced higher sebum levels than males..$^{20,21}$ Therefore, men should be at higher risk of developing more severe acne scar. However, the recent study did not find differences in skin type and the risk of more severe acne scar between gender. The absence of different skin types and acne scar severity between gender could not be explained.

We also noted some limitations of this study. First, sebum production should be measured precisely using sebumeter. This could establish sebum production and its relation with acne scar severity. Second, a less large sample size may affect the statistical significance and the proportional distribution of skin types and acne scar severity. Third, the impact of acne scar severity on quality of life in these participants should be evaluated to see its consequences on academic performance.

\section{CONCLUSION}

Our study demonstrated that skin type had a positive correlation with acne scar severity. Oily skin type was at 4.3 times greater risk of developing more severe acne scar.

\section{CONFLICT OF INTEREST}

The authors declare no conflict of interest.

\section{ACKNOWLEDGEMENT}

The authors would like thanks to all participants.

\section{REFERENCES}

1. Gollnick H, Cunliffe W, Berson D, Dreno B, Finlay A, Leyden JJ, et al. Management of acne: a report from a Global Alliance to Improve Outcomes in Acne. Journal of the American academy of dermatology. 2003;49(1):S1-37.

2. Djuanda A d. Ilmu penyakit kulit dan kelamin Edisi ketujuh. Jakarta: Fakultas Kedokteran Universitas Indonesia. 2016;

3. J Goodman G. Post-acne scarring: A short review of its pathophysiology. Australasian Journal of Dermatology. 2001;42(2):84-90.

4. Baumann LS. The Baumann Skin Typing System. In: Textbook of Aging Skin. Berlin, Heidelberg: Springer Berlin Heidelberg; 2010. p. 929-43.

5. Tanghetti EA. The role of inflammation in the pathology of acne. Journal of Clinical and Aesthetic Dermatology. 2013;6(9):2735.

6. Fabbrocini G, Annunziata MC, D'Arco V, De Vita V, Lodi G, Mauriello MC, et al. Acne scars: Pathogenesis, classification and treatment. Dermatology Research and Practice. 2010;2010. ID 893080.

7. Hayashi N, Miyachi Y, Kawashima M. Prevalence of scars and "mini-scars", and their impact on quality of life in Japanese patients with acne. Journal of Dermatology. 2015;42(7):690-6.

8. Revol O, Milliez N, Gerard D. Psychological impact of acne on 21st-century adolescents: Decoding for better care. British Journal of Dermatology. 2015;172(S1):52-8.

9. Skroza N, Tolino E, Mambrin A, Zuber S, Balduzzi V, Marchesiello A, et al. Adult acne versus adolescent acne: A retrospective study of 1,167 Patients. Journal of Clinical and Aesthetic Dermatology. 2018;11(1):21-5.

10. Goodman GJ, Baron JA. Postacne scarring: A qualitative global scarring grading system. Dermatologic Surgery. 2006;32(12):145866.

11. Kartinayanti NIWD. Korelasi antara kadar sebum dengan derajat parut akne pada penderita akne vulgaris. Yogyakarta: Universitas Gadjah Mada; 2015.

12. Yosipovitch G, Tang M, Dawn AG, Chen M, Goh CL, Chan YH, et al. Study of psychological stress, sebum production and acne vulgaris in adolescents. Acta Dermato-Venereologica. 2007;87(2):135-9.

13. Choi CW, Choi JW, Park KC, Youn SW. Facial sebum affects the development of acne, especially the distribution of inflammatory acne. Journal of the European Academy of Dermatology and Venereology. 2013;27(3):301-6.

14. Istiningdyah DA, Malik DA, Maharani N. 
Faktor-faktor yang mempengaruhi terjadinya skar akne. Fakultas Kedokteran Universitas Diponegoro; 2012.

15. Layton AM, Henderson CA, Cunliffe WJ. A clinical evaluation of acne scarring and its incidence. Clinical and Experimental Dermatology. 1994;19(4):303-8.

16. Holland DB, Jeremy AHT. The role of inflammation in the pathogenesis of acne and acne scarring. Seminars in Cutaneous Medicine and Surgery. 2005;24(2):79-83.

17. Li X, Galzote C, Yan X, Li L, Wang X. Characterization of Chinese body skin through in vivo instrument assessments, visual evaluations, and questionnaire: Influences of body area, inter-generation, season, sex, and skin care habits. Skin Research and Technology. 2014;20(1):14-22.

18. Luebberding $S$, Krueger N, Kerscher $M$. Skin physiology in men and women: In vivo evaluation of 300 people including TEWL, SC hydration, sebum content and skin surface $\mathrm{pH}$. International Journal of Cosmetic Science. 2013;35(5):477-83.

19. Chen W, Mempel M, Traidl-Hofmann C, Al Khusaei S, Ring J. Gender aspects in skin diseases. Journal of the European Academy of Dermatology and Venereology. 2010;24(12):1378-85.

20. Abdallah MAR, Zuelfakkar NM, Elbana RH. Comparative Study of Male and Female Sebum Production. The Egyptian Journal of Hospital Medicine. 2017;69(2):1874-9.

21. Sugawara T, Nakagawa N, Shimizu N, Hirai N, Saijo Y, Sakai S. Gender and age-related differences in facial sebaceous glands in Asian skin, as observed by non-invasive analysis using three-dimensional ultrasound microscopy. Skin Research and Technology. 2019;25(3):347-54. 